\title{
Erratum to: Post-ischemic early acidosis in cardiac postconditioning modifies the activity of antioxidant enzymes, reduces nitration, and favors protein $\mathrm{S}$-nitrosylation
}

\author{
Claudia Penna • Maria-Giulia Perrelli • Francesca Tullio • Francesca Moro • \\ Maria Laura Parisella • Annalisa Merlino • Pasquale Pagliaro
}

Published online: 11 October 2014

(C) Springer-Verlag Berlin Heidelberg 2014

Erratum to: Pflugers Arch - Eur J Physiol (2011) 462:219-233

DOI 10.1007/s00424-011-0970-1

The original publication of this article contains a mistake. In Fig 5 and in Fig 6 the same controls were incorrectly assembled for the final version of the figures and the correct controls are now shown. Moreover, we disclose in the legends that the presented bands were not juxtaposed in the original films.

Erratum for the Fig 5 and Fig 6 of the article: Penna, C., Perrelli, M.-G., Tullio, F., Moro, F., Parisella, M.L., Merlino, A., Pagliaro, P. Post-ischemic early acidosis in cardiac postconditioning modifies the activity of antioxidant enzymes, reduces nitration, and favors protein S-nitrosylation (2011) Pflugers Archiv European Journal of Physiology, 462

(2), pp. 219-233.

The online version of the original article can be found at http://dx.doi.org/ 10.1007/s00424-011-0970-1.

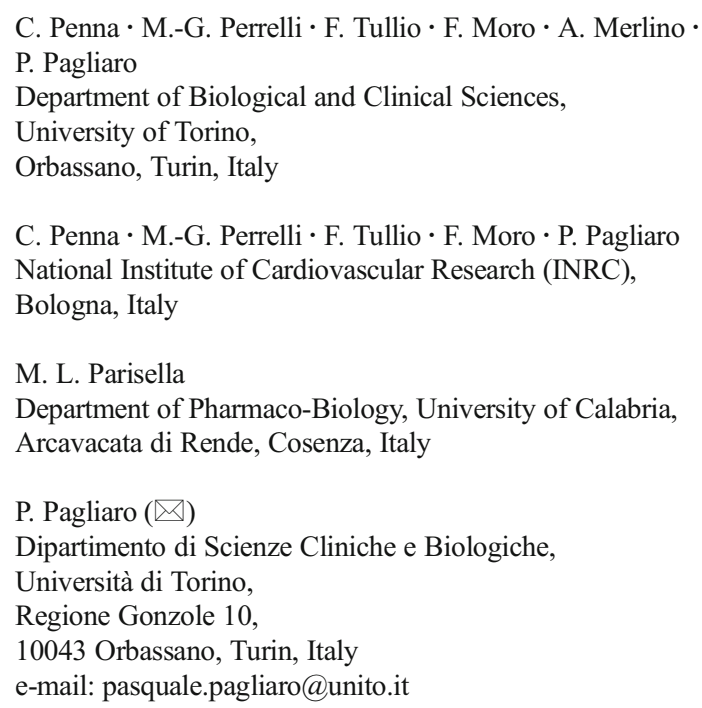


Fig. 5 Antioxidant enzyme protein levels analyzed by Western blot in Sham, ischemia/reperfusion (I/R), postconditioning (PostC), and acid buffer $(\mathrm{AB})$ hearts. a-c $\mathrm{Mn} / \mathrm{SOD}, \mathrm{Cu}-\mathrm{Zn} / \mathrm{SOD}$ and catalase, respectively, at $7^{\text {th }}$ min of reperfusion. d-f $\mathrm{Mn} / \mathrm{SOD}, \mathrm{Cu}-\mathrm{Zn} /$ SOD and Catalase, respectively, at $120^{\text {th }}$ min of reperfusion. Presented bands were not juxtaposed in the original films. Data in bar graph are mean $( \pm \mathrm{SE})$ and are presented as percent variation of baseline level. ${ }^{* *} p<0.01$ vs. Sham, ${ }^{\#} p<0.01$ vs.

I/R. $n=6$ for each group (for further explanation, see text)

\section{Antioxidant Enzyme Levels}

a

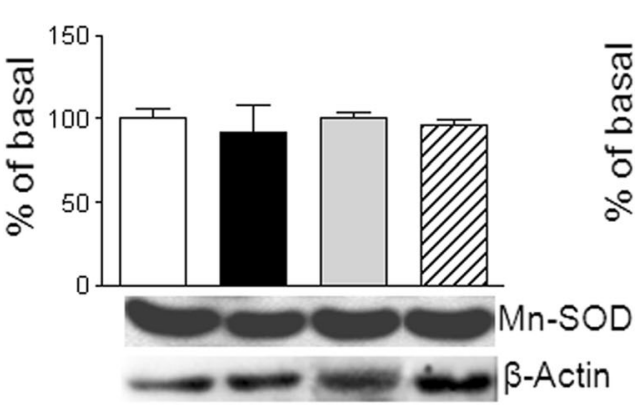

b

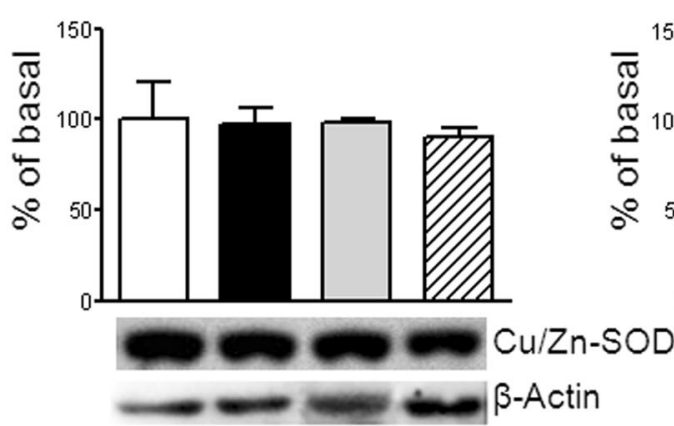

d Mn-SOD $120^{\text {th }} \mathrm{min}$

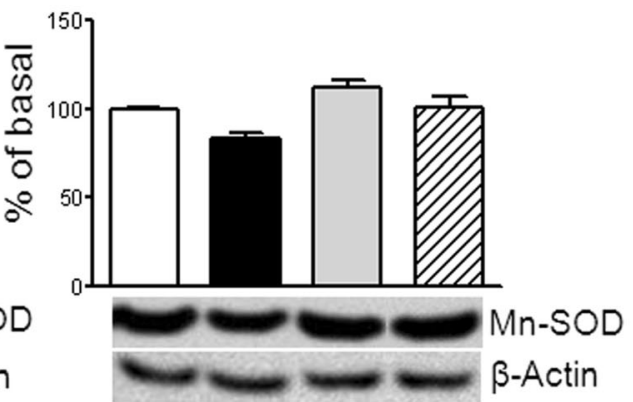

e $\quad \mathrm{Cu} / \mathrm{Zn}-\mathrm{SOD} 120^{\text {th }} \mathrm{min}$
C

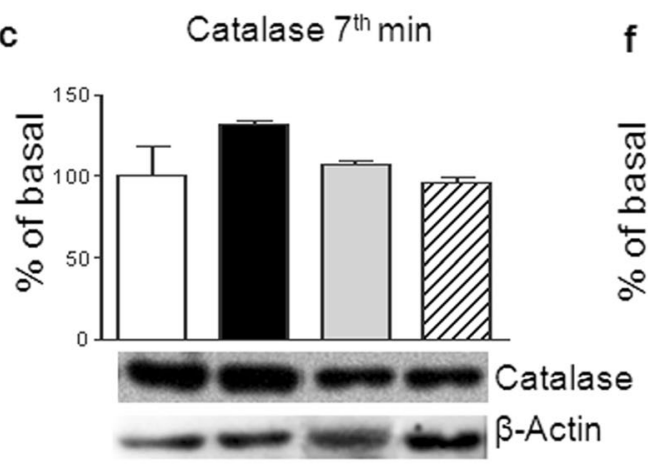

f Catalase $120^{\text {th }} \mathrm{min}$

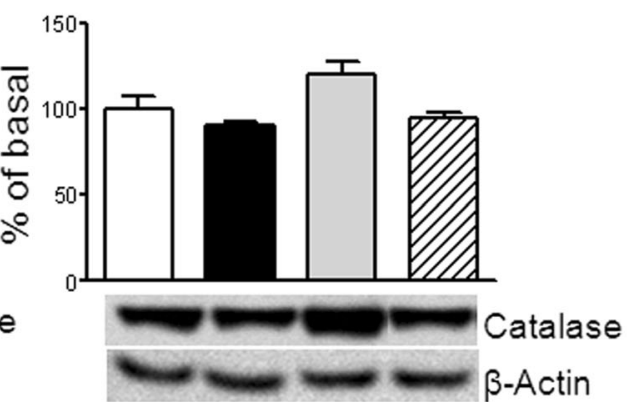

Sham

I/R

Postc $\square \mathrm{AB}$

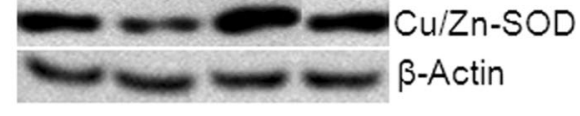


Fig. 6 S-nitrosylated proteins in Sham, ischemia/reperfusion (I/R), postconditioning (PostC), and

PostC+SOD hearts. a, c

Representative blots of Snitrosylated proteins in rat heart homogenates at $7^{\text {th }}$ and $120^{\text {th }}$ min of reperfusion, respectively. To control the specificity of the biotin switch assay, ascorbate has been omitted in Sham samples (-Asc). Presented bands were not juxtaposed in the original films. b, d The bar graphs are means ( \pm SE) of band concentrations at $7^{\text {th }}$ and $120^{\text {th }}$ min of reperfusion, respectively. Data are presented as percent variation of baseline level. ${ }^{*}<0.05,{ }^{* *} p<0.01 v s$. Sham; ${ }^{\#} p<0.05$ vs. I/R; ${ }^{{ }} p<0.05$ vs. PostC; ${ }_{\mathrm{p}}<0.05 v \mathrm{vs}$. corresponding group at the $7^{\text {th }}$ min of reperfusion. NS nonsignificant. $n=6$ for each group

\section{S-nitrosylated Proteins}

b

a

B-Actin

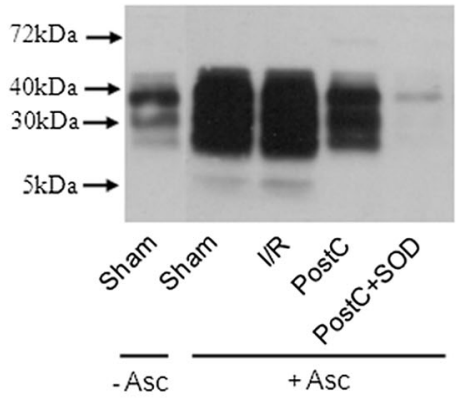

C

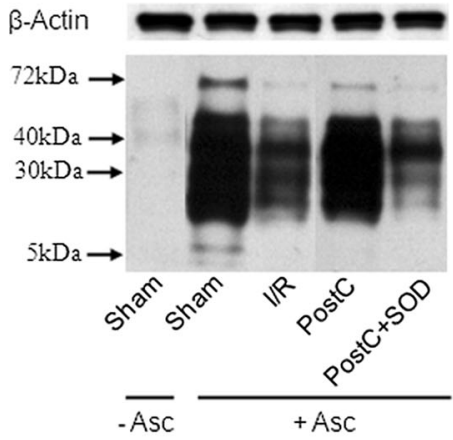

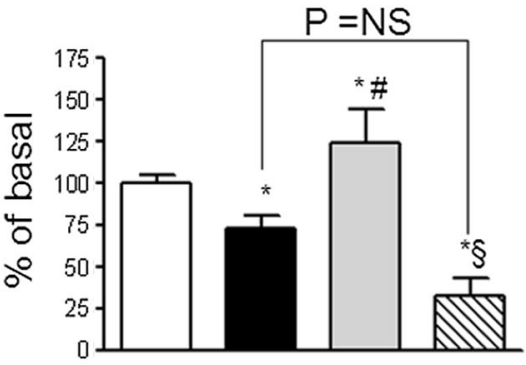

d

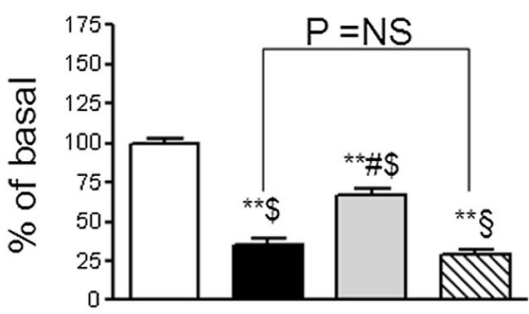

